\title{
Boost Converter with a Transformer Capacitor Cell for Implementing Features of Zero-voltage Switching/ Zero-current Switching and Double-output Sources
}

\author{
Cheng-Tao Tsai, ${ }^{1 *}$ Jye-Chau Su, ${ }^{2}$ and $\mathrm{Sin}-\mathrm{Ru} \mathrm{Wei}^{1}$ \\ ${ }^{1}$ Department of Electrical Engineering, National Chin-Yi University of Technology, \\ No. 57, Sec. 2, Zhongshan Rd, Taiping Dist, Taichung 41170, Taiwan \\ ${ }^{2}$ Department of Electronic Engineering, National Chin-Yi University of Technology, \\ No. 57, Sec. 2, Zhongshan Rd, Taiping Dist, Taichung 41170, Taiwan
}

(Received May 23, 2018; accepted October 18, 2018)

Keywords: transformer capacitor, double output, ZVS/ZCS, EMI, reverse recovery

In this paper, a boost converter with a transformer capacitor cell for implementing features of double-output sources and zero-voltage switching (ZVS)/zero-current switching (ZCS) is proposed. The proposed boost converter has the following advantages: (1) By incoporating a transformer capacitor cell, the main switch can achieve ZVS and the auxiliary switch can achieve ZCS under turn-on transitions, reducing switching losses and electromagnetic interference (EMI). Therefore, the conversion efficiency and power quality of the proposed boost converter can be increased. (2) By applying the turn ratio of the transformer, the proposed boost converter can obtain double-output sources with step-up and step-down voltage functions. (3) The leakage energy of the transformer can be recovered using a capacitor, and then the energy of the capacitor can limit the reverse recovery current of power diodes, reducing reverse recovery losses. Finally, a boost converter prototype with a transformer capacitor cell for implementing the features of ZVS/ZCS and double-output sources is built. The performance and feasibility of the proposed boost converter have been verified from the simulated and experimental results.

\section{Introduction}

Energy is essential to our society to ensure our quality of life and to underpin all other elements of our economy. Owing to rapid developments in industry and commerce, the global requirement and consumption of energy have increased markedly. Essentially, the majority of the energy demand for modern civilization comes from fossil fuels (e.g., coal, oil, and natural gas). However, fossil fuels form very slowly in comparison with the rate of energy use, and thus they are considered limited resources and will be exhausted in the near future. Therefore, developing clean energy sources to substitute for fossil fuels has been an important topic. ${ }^{(1-3)}$ One of these sources is a hydrogen fuel cell, which is clean, quiet, and efficient for generating

*Corresponding author: e-mail: cttsai@ncut.edu.tw https://doi.org/10.18494/SAM.2019.2086 
electricity. A fuel cell is an electrochemical device that directly converts chemical energy into electrical energy without combustion. In general, the output voltage of the fuel cell is usually relatively low, which requires a step-up converter for practical applications, as shown in Fig. 1.

To achieve step-up voltage ratio, a boost converter is usually the right choice. It has simple constructions and widely used at low and medium power, as shown in Fig. 2. Unfortunately, the boost converter operated at a high frequency in a hard-switching manner results in high switching losses, a severe electromagnetic interference (EMI), and a low conversion efficiency. ${ }^{(4-7)}$ The linear approximation of typical current and voltage switching waveforms for the power switch is shown in Fig. 3. In addition, to obtain good power regulation and protection mechanisms, the boost converter needs extra pulse-width-modulated (PWM) controllers and protection circuits. In general, the powers of the PWM controllers and protection circuits usually use lower voltage, such as $5,12,15$, or $24 \mathrm{~V}$. To meet these requirements, the boost converter must provide a set of extra power with lower voltage, resulting in circuit complexity and cost. Therefore, the boost converter with double-output sources of step-up and step-down voltage functions can meet the requirement of low voltage.

From Fig. 3, the total switching loss is given as

$$
\begin{aligned}
P_{\text {total }, \text { swit }} & =\frac{1}{T_{S}} \int_{0}^{T_{s}} p(t) d t \\
& =\frac{1}{T_{S}}\left[\int_{0}^{t_{o n}}-\frac{V_{o f f} I_{o n}}{t_{o n}^{2}}\left(t-t_{o n}\right) t d t+\int_{T_{s}-t_{o f f}}^{T_{s}}-\frac{V_{o f f} I_{o n}}{t_{o f f}^{2}}\left(t-\left(T_{s}-t_{o f f}\right)\right)\left(t-T_{s}\right) d t\right] .
\end{aligned}
$$

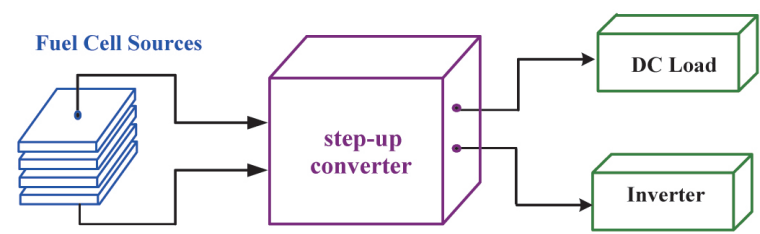

Fig. 1. (Color online) Illustration of a fuel cell power supply.

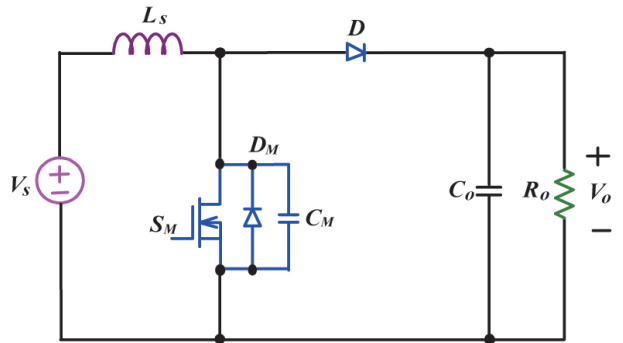

Fig. 2. (Color online) Topology of boost converter.

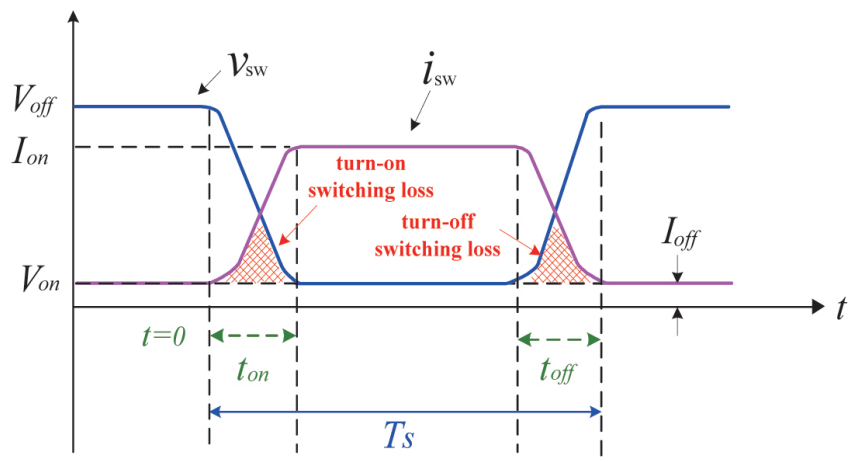

Fig. 3. (Color online) Linear approximation of typical current and voltage switching waveforms for power switch. 
The evaluation of the integral is given as

$$
P_{\text {total }, \text { swit }}=\frac{V_{\text {off }} I_{\text {on }}}{T_{s}}\left(\frac{t_{\text {on }}+t_{\text {off }}}{6}\right)
$$

From the above analysis results, we note that as the frequency increases, the switching loss increases significantly. To solve this problem, several zero-voltage switching (ZVS) and zerocurrent switching (ZCS) techniques are reported in the literature. ${ }^{(8-13)}$ The use of the boost converter with ZVS and ZCS techniques will result in the absence of voltage and current across the power switch at turn-on and turn-off transitions, as illustrated in Figs. 4 and 5. Therefore, the power switch of boost can significantly decrease the switching loss and increase the conversion efficiency.

\section{Derivations of the Proposed Converter}

Recently, soft-switching techniques have been classified as ZVS and ZCS techniques. A basic soft-switching cell consists of a resonant inductor $\left(L_{r}\right)$, an auxiliary switch $\left(S_{a}\right)$ with a body diode $\left(D_{a}\right)$ and a parasitic capacitor $\left(C_{a}\right)$, and a diode $\left(D_{b}\right)$, as shown in Fig. 6 . The basic soft-switching cell can be incorporated in the buck, boost, buck-boost, 'cuk, zeta, and sepic converters to create ZVS and ZCS features at turn-on and turn-off transitions. ${ }^{(13-17)}$ These nonisolated converters with the ZVS/ZCS cell are shown in Fig. 7.

For example, Fig. 7(b) shows a boost converter with a soft-switching cell to achieve the ZVS of the main switch $\left(S_{M}\right)$ and the ZCS of the auxiliary switch $\left(S_{a}\right)$ under turn-on transitions. Its key voltage and current waveforms are shown in Fig. 8, from which it can be seen that the current and voltage waveforms of the power switches in the boost converter are essentially

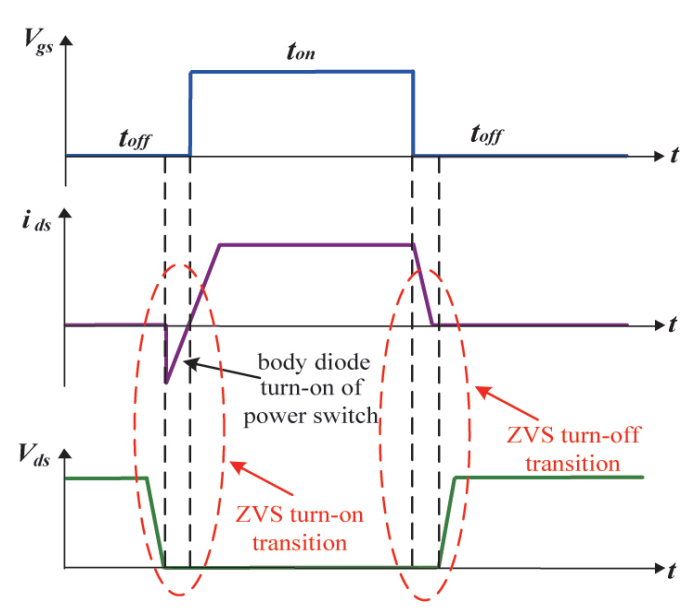

Fig. 4. (Color online) Illustration of ZVS turn-on and turn-off conditions.

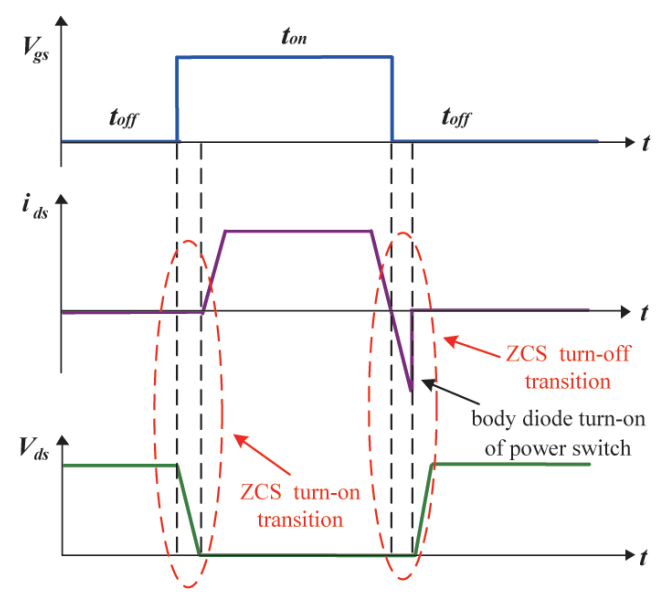

Fig. 5. (Color online) Illustration of ZCS turn-on and turn-off conditions. 


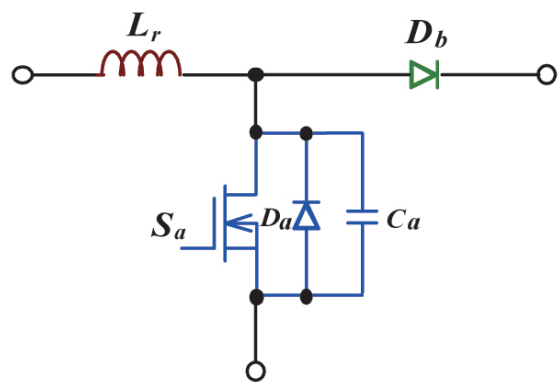

Fig. 6. (Color online) Topology of a basic soft-switching cell.

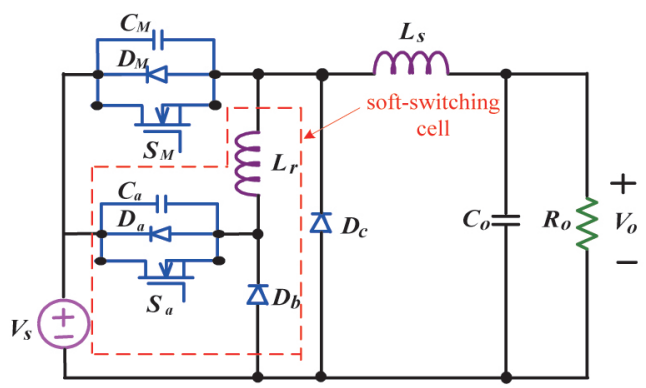

(a)

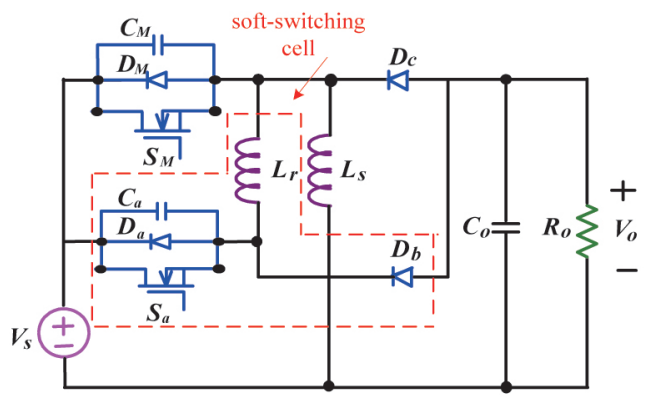

(c)

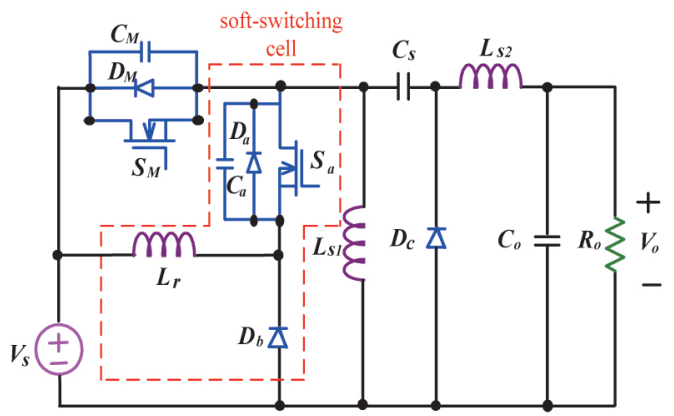

(e)

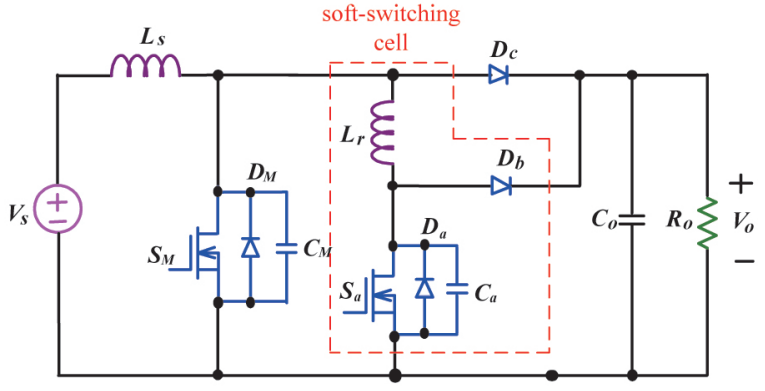

(b)

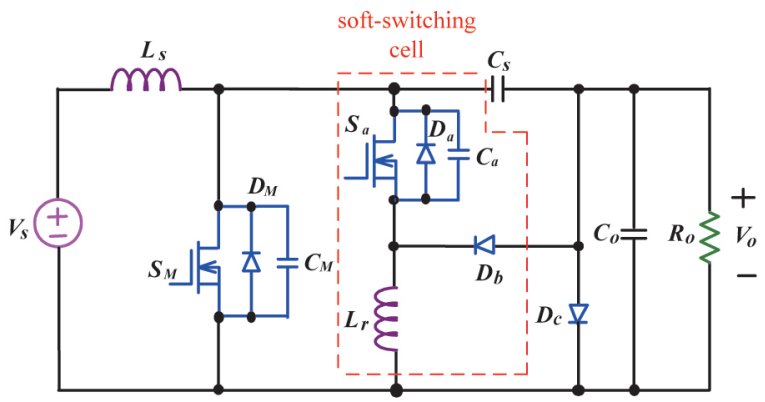

(d)

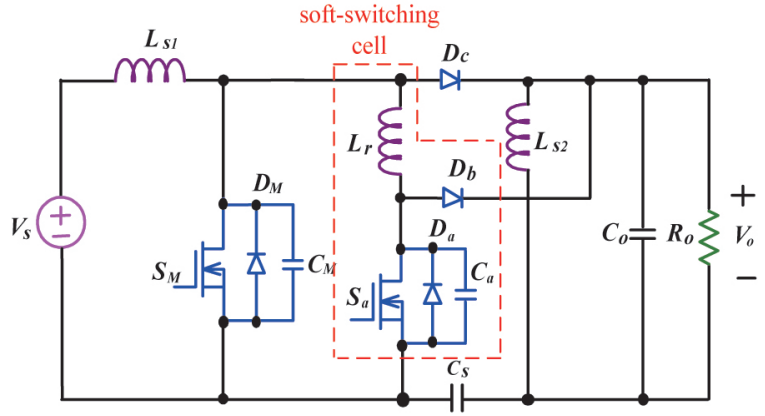

(f)

Fig. 7. (Color online) Topologies of nonisolated converters with a basic soft-switching cell. (a) Buck converter, (b) boost converter, (c) buck-boost converter, (d) 'cuk converter, (e) zata converter, and (f) sepic converter. 


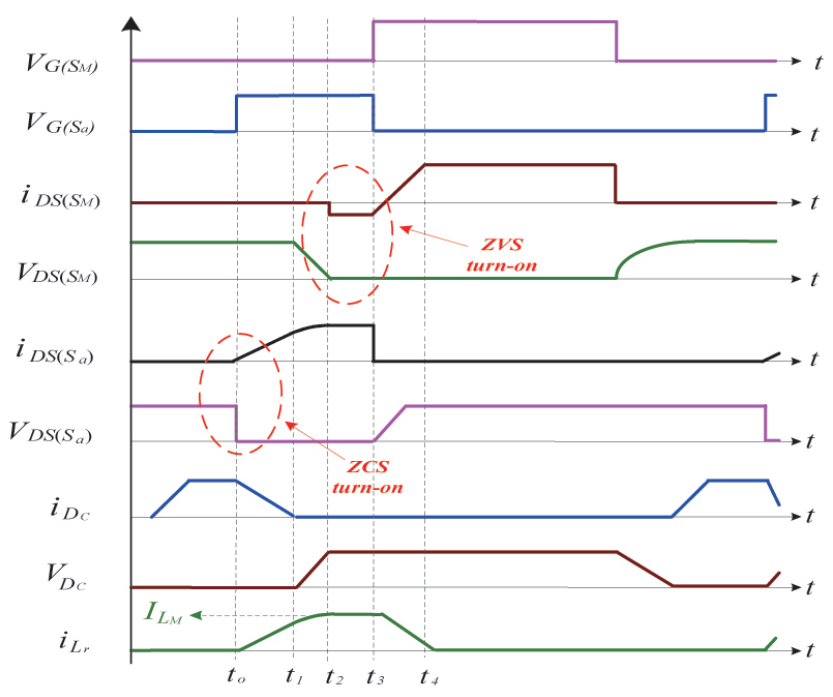

Fig. 8. (Color online) Current and voltage waveforms of the key components and the driving signal switches $\left(S_{M}\right.$ and $S_{a}$ ) for a ZVS/ZCS boost converter.

square-wave except at the turn-on and turn-off switching intervals. At the time $t_{0}$, the auxiliary switch $\left(S_{a}\right)$ is turned on and the current of the resonant inductor, $i_{L r}$, is linearly built up. Since the resonant inductor $\left(L_{r}\right)$ limits the change rate of $d i / d t$, the auxiliary switch $\left(S_{a}\right)$ is turned on under the ZCS condition. At the time interval $t_{1}-t_{2}$, the parasitic capacitor $\left(C_{M}\right)$ of the main switch $\left(S_{M}\right)$ resonates with a resonant inductor $\left(L_{r}\right)$ to discharge the energy stored in the parasitic capacitor $\left(C_{M}\right)$. This mode is not terminated until the voltage $V_{d s(S M)}$ of the main switch $\left(S_{M}\right)$ is dropped to zero, and then the body diode $\left(D_{M}\right)$ of the main switch $\left(S_{M}\right)$ will conduct. Thus, a ZVS/ZCS operational opportunity is created.

As shown in Fig. 7(b), to obtain double-output sources and increase the utility of the boost converter, the resonant inductor $\left(L_{r}\right)$ of the basic soft-switching cell can be replaced with a transformer. Therefore, the basic soft-switching cell in Fig. 7(b) can be modified with a transformer cell, as shown in Fig. 9. Unfortunately, the leakage inductance $\left(L_{k}\right)$ of the transformer $\left(T_{r}\right)$ at the auxiliary switch $\left(S_{a}\right)$ is turned off during transition, increasing the voltage spike of the auxiliary switch $\left(S_{a}\right)$ and inducing a significant EMI. To solve these problems, a passive lossless snubber with two power diodes and a capacitor is incorporated, as shown in Fig. 9. Such a snubber must provide a conduction path when the auxiliary switch $\left(S_{a}\right)$ is turned off. If there is no path provided, either device might be destroyed by a voltage spike. Thus, as shown in Fig. 10, two power diodes $\left(D_{e}\right.$ and $\left.D_{f}\right)$ and one buffer capacitor $\left(C_{3}\right)$ are added to recover the leakage energy of the transformer $\left(T_{r}\right)$. Additionally, the buffer capacitor $\left(C_{3}\right)$ can also limit the decrease in the current rate of the power diodes $\left(D_{c}\right.$ and $\left.D_{f}\right)$, reducing diode reverse-recovery losses. $^{(18-20)}$ Finally, a boost converter with a transformer capacitor cell for implementing the features of ZVS/ZCS and double-output sources is proposed. 


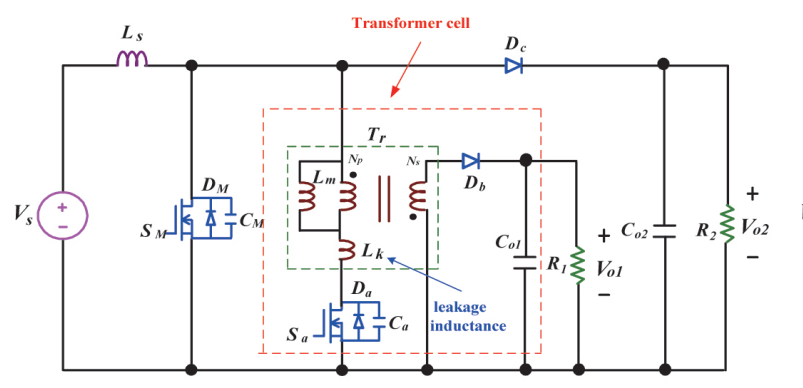

Fig. 9. (Color online) Topology of a boost converter with a transformer cell for implementing features of ZVS/ZCS and double-output sources.

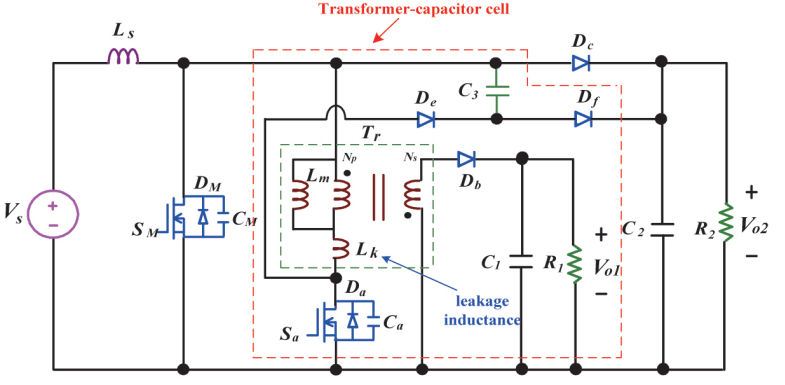

Fig. 10. (Color online) Illustration of the proposed boost converter with a transformer capacitor cell for implementing features of ZVS/ZCS and doubleoutput sources.

In this study, a boost converter with a transformer capacitor cell for implementing features of ZVS/ZCS and double-output sources is proposed, as shown in Fig. 10. The proposed boost converter has the following advantages:

(1) The switching loss and EMI of power switches can be reduced by incorporating a transformer-capacitor cell.

(2) The utility of the double-output sources with step-up/step-down voltage functions can be maximized.

(3) The leakage energy of the transformer can be recovered in a capacitor. Then, the energy of the capacitor can limit the reverse-recovery current of the power diodes, reducing reverserecovery losses.

The operational principles of the proposed boost converter are described in Sect. 3. The considerations of design and simulated experimental results are described in Sects. 4 and 5, respectively. Finally, conclusions are given in Sect. 6.

\section{Operational Principles}

As shown in Fig. 10, the proposed boost converter with a transformer capacitor cell for implementing the features of ZVS/ZCS and double-output sources consists of a conventional boost converter and a transformer-capacitor cell. The transformer-capacitor cell is composed of an auxiliary switch $\left(S_{a}\right)$, a transformer $\left(T_{r}\right)$, a power diode $\left(D_{b}\right)$, and a filter capacitor $\left(C_{1}\right)$ to create a ZVS condition for the main switch $S_{M}$ and a ZCS condition for the auxiliary switch $S_{a}$. Additionally, a storage capacitor $\left(C_{3}\right)$ and two power diodes $\left(D_{e}\right.$ and $\left.D_{f}\right)$ are used to recover the energy of leakage inductance $\left(L_{k}\right)$ and reduce the reverse-recovery losses of power diodes $\left(D_{c}\right.$ and $D_{f}$ ). To apply the voltage ratio of the transformer $\left(T_{r}\right)$, the proposed boost converter can obtain another output source with step-down voltage.

As shown in Fig. 10, the operational principles of the proposed boost converter with a transformer capacitor cell for implementing the features of ZVS/ZCS and double-output sources over one switching cycle can be divided into nine major operating modes. Figure 11 shows the current and voltage waveforms of the key components and the driving signals of the switches 


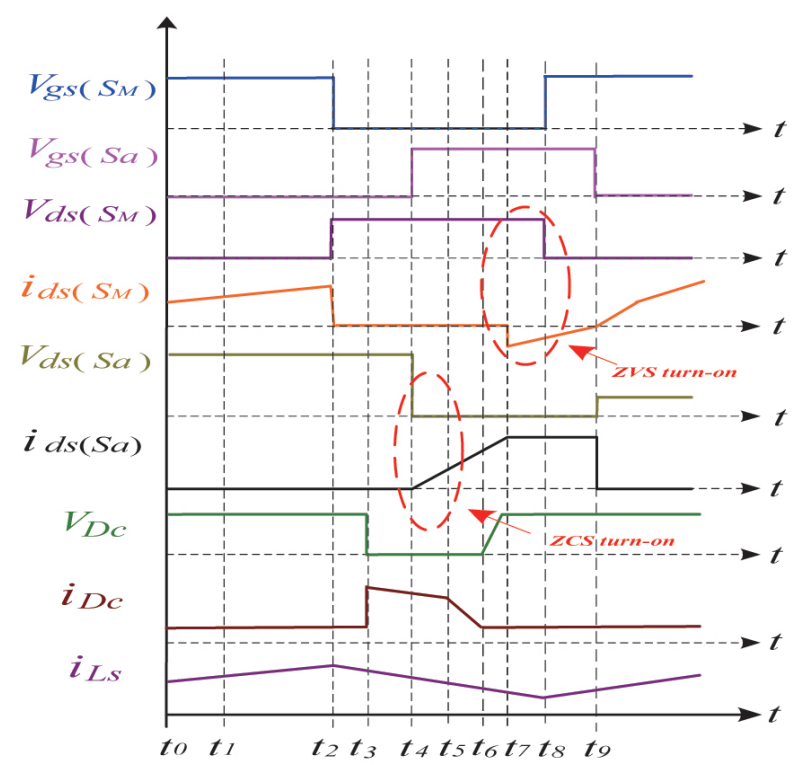

Fig. 11. (Color online) Current and voltage waveforms of the key components and driving signals of switches ( $S_{M}$ and $S_{a}$ ) for the proposed boost converter with a transformer-capacitor cell for implementing the features of ZVS/ZCS and double-output sources.

$\left(S_{M}\right.$ and $S_{a}$ ). Figure 12 shows the equivalent circuit modes of the proposed power converter. To simplify the description of the operational modes, the following assumptions are made:

To analyze the ZVS feature, the body diode $\left(D_{M}\right)$ and parasitic capacitor $\left(C_{M}\right)$ of the main switch $\left(S_{M}\right)$ will be considered in the steady-state operation of the circuit.

Filter and storage capacitors $\left(C_{1}, C_{2}\right.$, and $\left.C_{3}\right)$ are large enough such that the voltages across them are constant over a switching cycle.

All magnetic components, power switches, and power diodes are ideal.

\section{Mode 1 [Fig. 12(a), $t_{0}<t<t_{1}$ ]:}

At the time $t_{0}$, the main switch $\left(S_{M}\right)$ is turned on and the auxiliary switch $\left(S_{a}\right)$ is turned off. The inductor current $i_{L S}$ flowing through the path of $V_{S} \rightarrow L_{S} \rightarrow S_{M}$ is linearly increased. The inductor current $i_{L S}$ can be expressed as

$$
i_{L s}(t)=\frac{V_{s}}{L_{s}}\left(t-t_{0}\right)
$$

During this interval, the energy trapped in the leakage inductance $\left(L_{k}\right)$ of the transformer $\left(T_{r}\right)$ is transferred to the capacitor $\left(C_{3}\right)$ by power diode $\left(D_{e}\right)$ conduction. At this time, the energy stored in the magnetic inductance $\left(L_{m}\right)$ of the transformer $\left(T_{r}\right)$ is transferred to the first load $\left(R_{1}\right)$ by power diode $\left(D_{b}\right)$ conduction, and the current of the first load, $i_{R 1}$, can be expressed as

$$
i_{R 1}(t)=\frac{V_{o 1}}{L_{m}}\left(\frac{N_{p}}{N_{s}}\right)\left(t-t_{0}\right)
$$




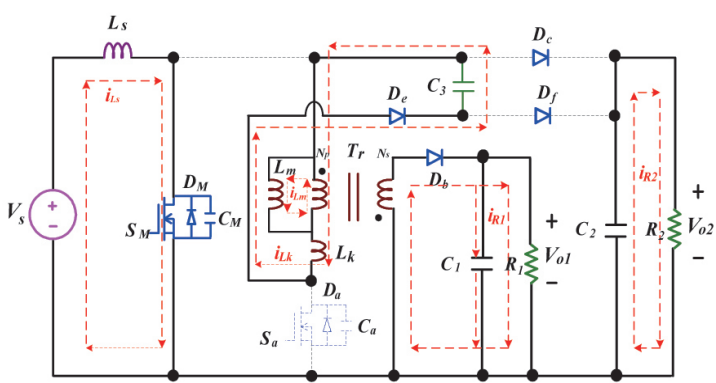

(a)

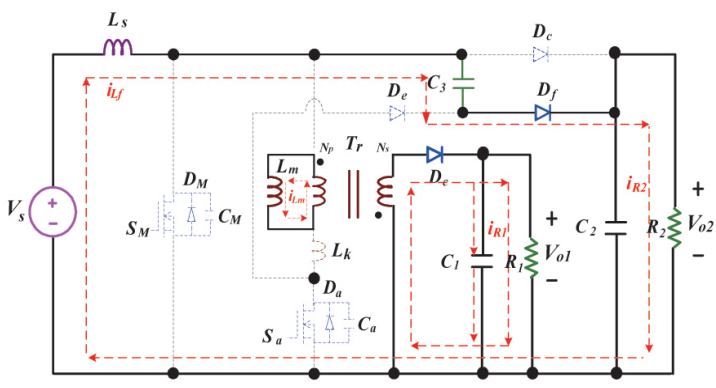

(c)

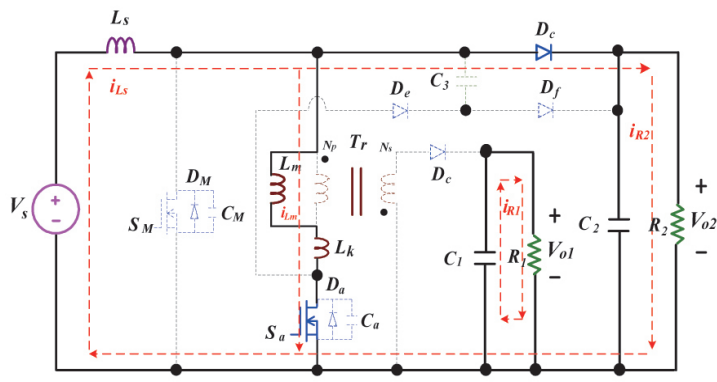

(e)

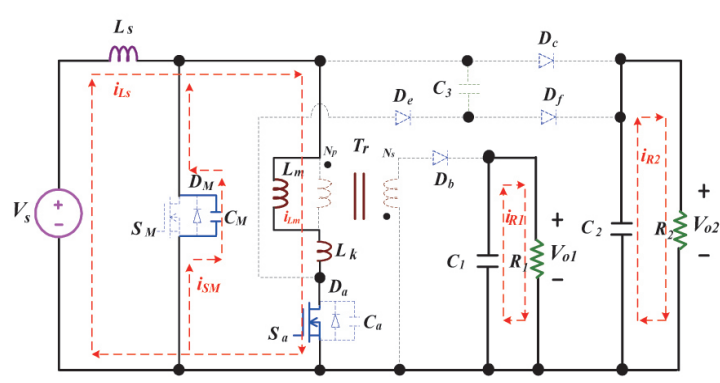

(g)

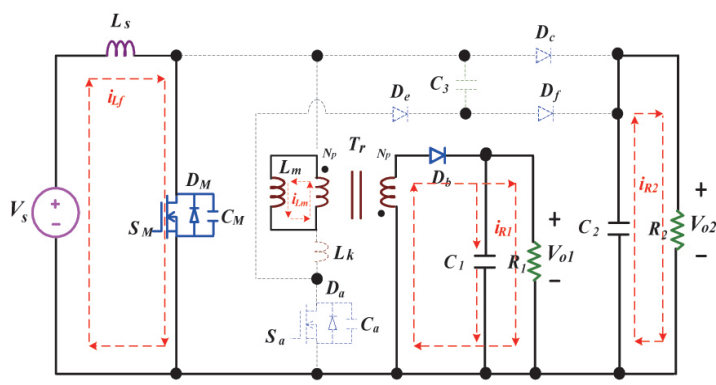

(b)

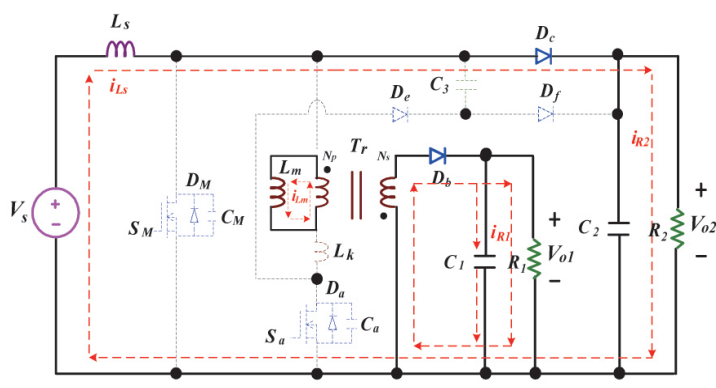

(d)

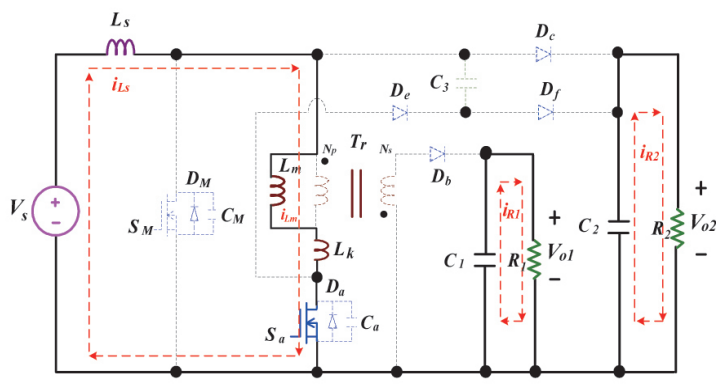

(f)

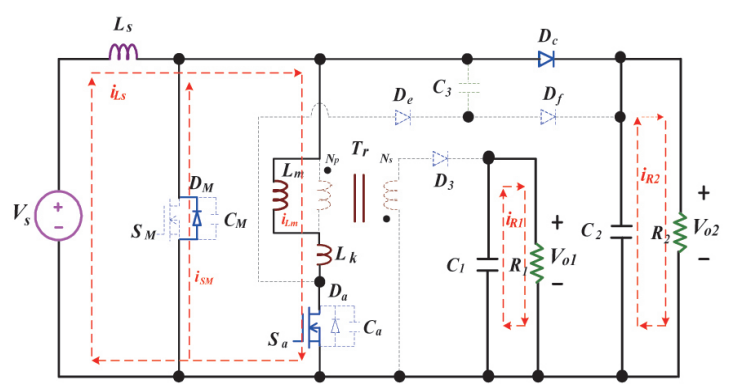

(h)

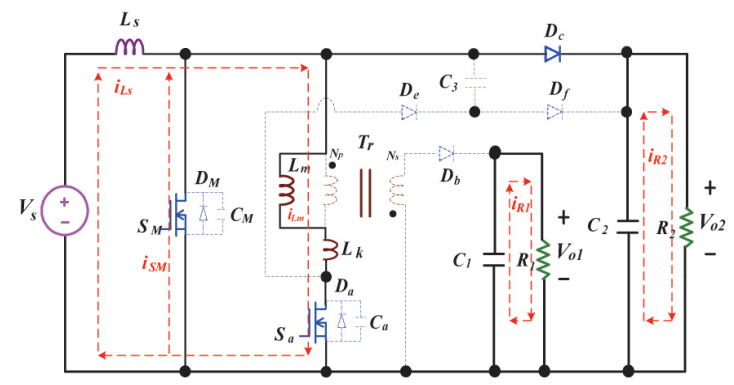

(i)

Fig. 12. (Color online) Equivalent circuits of the proposed boost converter with a transformer capacitor cell for implementing features of ZVS/ZCS and double-output sources. (a)-(i) correspond to Modes 1-9, respectively. 
where $N_{p}$ is the number of primary winding turns and $N_{s}$ is that of secondary winding turns of the transformer $\left(T_{r}\right)$. At this interval, the power diodes $\left(D_{c}\right)$ and $\left(D_{f}\right)$ are turned off and the filter capacitor $\left(C_{2}\right)$ delivers power to the secondary load $\left(R_{2}\right)$. The current of the secondary load, $i_{R 2}$, can be expressed as

$$
i_{R 2}(t)=\frac{V_{o 2}}{R_{2}}\left(t-t_{0}\right)
$$

The equivalent circuit is shown in Fig. 12(a).

Mode 2 [Fig. 12(b), $t_{1}<t<t_{2}$ ]:

At the time $t_{1}$, the main switch $\left(S_{M}\right)$ is maintained on, and the auxiliary switch $\left(S_{a}\right)$ is maintained off. Although the energy stored in the leakage inductance $\left(L_{k}\right)$ of the transformer $\left(T_{r}\right)$ drops to zero, the power diode $\left(D_{e}\right)$ turns off naturally. During this interval, the energy of the magnetic inductance $\left(L_{m}\right)$ continuously delivers power to the first load $\left(R_{1}\right)$, and the filter capacitors $\left(C_{2}\right)$ continuously deliver power to the secondary load $\left(R_{2}\right)$. The inductor current $i_{L s}$ can be expressed as

$$
i_{L s}(t)=\frac{V_{s}}{L_{S}}\left(t-t_{1}\right)
$$

and the currents of the first load, $i_{R 1}$, and secondary load, $i_{R 2}$, can be expressed as

$$
\begin{gathered}
i_{R 1}(t)=\frac{V_{o 1}}{L_{m}}\left(\frac{N_{p}}{N_{s}}\right)\left(t-t_{1}\right), \\
i_{R 2}(t)=\frac{V_{o 2}}{R_{2}}\left(t-t_{1}\right) .
\end{gathered}
$$

The equivalent circuit is shown in Fig. 12(b).

\section{Mode 3 [Fig. 12(c), $t_{2}<t<t_{3}$ ]:}

At the time $t_{2}$, the main switch $\left(S_{M}\right)$ is turned off and the auxiliary switch $\left(S_{a}\right)$ is maintained off. The inductor current $i_{L S}$ flowing through the path of $V_{S} \rightarrow L_{S} \rightarrow C_{3} \rightarrow D_{c} \rightarrow R_{2}$ is linearly decreased, and the storage capacitor $\left(C_{3}\right)$ begins discharging. The inductor current $i_{L s}$ can be expressed as

$$
i_{L s}(t)=\frac{\left(V_{s}-V_{c 3}-V_{o 2}\right)}{L_{S}}\left(t-t_{0}\right) .
$$

The energy of the magnetic inductance $\left(L_{m}\right)$ continuously delivers power to the first load $\left(R_{1}\right)$, and the filter capacitors $\left(C_{2}\right)$ continuously deliver power to the secondary load $\left(R_{2}\right)$. The currents of the first load, $i_{R 1}$, and secondary load, $i_{R 2}$, can be expressed as 


$$
\begin{gathered}
i_{R 1}(t)=\frac{V_{o 1}}{L_{m}}\left(\frac{N_{p}}{N_{s}}\right)\left(t-t_{2}\right), \\
i_{R 2}(t)=\frac{V_{o 2}}{R_{2}}\left(t-t_{2}\right) .
\end{gathered}
$$

The equivalent circuit is shown in Fig. 12(c).

Mode 4 [Fig. 12(d), $t_{3}<t<t_{4}$ ]:

At the time $t_{3}$, the main and auxiliary switches $\left(S_{M}\right.$ and $\left.S_{a}\right)$ are maintained off. When the voltage of the capacitor $\left(C_{3}\right)$ is discharged to zero, the power diode $\left(D_{c}\right)$ conducts naturally. The inductor current $i_{L S}$ flows through the path of $V_{S} \rightarrow L_{s} \rightarrow D_{e} \rightarrow R_{2}$, which can be expressed as

$$
i_{L S}(t)=\frac{\left(V_{S}-V_{o 2}\right)}{L_{S}}\left(t-t_{3}\right) .
$$

During this interval, the energy of the magnetic inductance $\left(L_{m}\right)$ continuously delivers power to the first load $\left(R_{1}\right)$, and the filter capacitors $\left(C_{2}\right)$ continuously deliver power to the secondary load $\left(R_{2}\right)$. The currents of the first load, $i_{R 1}$, and secondary load, $i_{R 2}$, can be expressed as

$$
\begin{gathered}
i_{R 1}(t)=\frac{V_{o 1}}{L_{m}}\left(\frac{N_{p}}{N_{s}}\right)\left(t-t_{3}\right), \\
i_{R 2}(t)=\frac{V_{o 2}}{R_{2}}\left(t-t_{3}\right) .
\end{gathered}
$$

The equivalent circuit is shown in Fig. 12(d).

\section{Mode 5 [Fig. 12(e), $t_{4}<t<t_{5}$ ]:}

At the time $t_{4}$, the main switch $\left(S_{M}\right)$ is maintained off and the auxiliary switch $\left(S_{a}\right)$ is turned on. Since the magnetic inductance $\left(L_{m}\right)$ of the transformer $\left(T_{r}\right)$ limits the change rate of di/dt, the auxiliary switch $\left(S_{a}\right)$ is turned on with a ZCS feature. The inductor current $i_{L s}$ is divided into two paths ( $i_{L m}$ and $i_{R 2}$ ), namely, $V_{s} \rightarrow L_{s} \rightarrow L_{m} \rightarrow L_{k} \rightarrow S_{a}$ and $V_{s} \rightarrow L_{s} \rightarrow D_{e} \rightarrow R_{2}$. The current of the two paths $\left(i_{L m}\right.$ and $\left.i_{R 2}\right)$ can be expressed as

$$
\begin{gathered}
i_{L s}(t)=i_{L m}(t)+i_{R 2}(t), \\
i_{L m}(t)=\frac{V_{L m}}{L_{m}}\left(t-t_{4}\right), \\
i_{R 2}(t)=\frac{V_{s}-V_{o 2}}{R_{2}}\left(t-t_{4}\right) .
\end{gathered}
$$


During this interval, the power diode $\left(D_{b}\right)$ is turned off and the filter capacitor $\left(C_{1}\right)$ delivers power to the first load $\left(R_{1}\right)$. The current of the first load, $i_{R 1}$, can be expressed as

$$
i_{R 1}(t)=\frac{V_{o 1}}{R_{1}}\left(t-t_{4}\right)
$$

The equivalent circuit is shown in Fig. 12(e).

Mode 6 [Fig. 12(f), $\boldsymbol{t}_{5}<\boldsymbol{t}<\boldsymbol{t}_{\mathbf{6}}$ ]:

At the time $t_{5}$, the main switch $\left(S_{M}\right)$ is maintained off and the auxiliary switch $\left(S_{a}\right)$ is maintained on. When the inductor current $i_{L s}$ equals the magnetic current $i_{L m}$ of the transformer, the power diode $\left(D_{C}\right)$ turns off naturally. The inductor current $i_{L S}$ can be expressed as

$$
i_{L s}(t)=i_{L m}(t)=\frac{V_{L m}}{L_{m}}\left(t-t_{5}\right)
$$

During this interval, filter capacitors $\left(C_{1}\right.$ and $\left.C_{2}\right)$ particularly deliver power to the first load $\left(R_{1}\right)$ and secondary load $\left(R_{2}\right)$. The currents of the first load, $i_{R 1}$, and secondary load, $i_{R 2}$, can be expressed as

$$
\begin{gathered}
i_{R 1}(t)=\frac{V_{o 1}}{L_{m}}\left(\frac{N_{p}}{N_{s}}\right)\left(t-t_{5}\right), \\
i_{R 2}(t)=\frac{V_{o 2}}{R_{2}}\left(t-t_{5}\right) .
\end{gathered}
$$

The equivalent circuit is shown in Fig. 12(f).

Mode 7 [Fig. 12(g), $t_{6}<t<t_{7}$ ]:

At the time $t_{6}$, the main switch $\left(S_{M}\right)$ is maintained off and the auxiliary switch $\left(S_{a}\right)$ is maintained on. When the inductor current $i_{L s}$ is less than the magnetic current $i_{L m}$ of the transformer, the magnetic current $i_{L m}$ is divided into two paths $\left(i_{L s}\right.$ and $\left.i_{S M}\right)$. One path is $V_{S} \rightarrow$ $L_{s} \rightarrow L_{m} \rightarrow S_{a}$, and the other path is $L_{m} \rightarrow S_{a} \rightarrow C_{M}$. In this mode, the magnetic inductance $\left(L_{m}\right)$ of the transformer $\left(T_{r}\right)$ releases its energy to the parasitic capacitance $\left(C_{M}\right)$ of the main switch $\left(S_{M}\right)$ in a resonant manner. The current $i_{S M}$ and the voltage $V_{D S(S M)}$ of the main switch $\left(S_{M}\right)$ can be expressed as

$$
\begin{gathered}
i_{S M}(t)=\frac{V_{o 2}}{Z_{a}} \sin \omega\left(t-t_{6}\right), \\
V_{D S(S M)}(t)=V_{02} \cos \omega\left(t-t_{6}\right),
\end{gathered}
$$


where $\omega=\frac{1}{\sqrt{L_{m} \cdot Z_{a}}}$ is the resonant frequency and $Z_{a}=\sqrt{\frac{L_{m}}{C_{M}}}$ is the characteristic impedance. The resonant time can be expressed as

$$
T_{\text {resonant }}=t_{7}-t_{6}=\frac{\pi}{2 \omega}=\frac{\pi}{2} \sqrt{L_{m} C_{M}} .
$$

During this interval, the filter capacitors $\left(C_{1}\right.$ and $\left.C_{2}\right)$ continuously deliver power to the first load $\left(R_{1}\right)$ and secondary load $\left(R_{2}\right)$. The currents of the first load, $i_{R 1}$, and secondary load, $i_{R 2}$, can be expressed as

$$
\begin{gathered}
i_{R 1}(t)=\frac{V_{o 1}}{L_{m}}\left(\frac{N_{p}}{N_{s}}\right)\left(t-t_{6}\right), \\
i_{R 2}(t)=\frac{V_{o 2}}{R_{2}}\left(t-t_{6}\right) .
\end{gathered}
$$

The equivalent circuit is shown in Fig. 12(g).

Mode 8 [Fig. 12(h), $t_{7}<t<t_{8}$ ]:

At the time $t_{7}$, the main switch $\left(S_{M}\right)$ is maintained off and the auxiliary switch $\left(S_{a}\right)$ is maintained on. When the voltage $V_{D S(S M)}$ of the parasitic capacitance $\left(C_{M}\right)$ is discharged to zero, the body diode $\left(D_{M}\right)$ of the main switch $\left(S_{M}\right)$ conducts, creating a ZVS condition for the main switch $\left(S_{M}\right)$. The current $i_{S M}$ of the main switch $\left(S_{M}\right)$ can be expressed as

$$
i_{S M}(t)=\frac{V_{o 2}}{L_{m}}\left(t-t_{7}\right),
$$

During this interval, filter capacitors $\left(C_{1}\right.$ and $\left.C_{2}\right)$ continuously deliver power to the first load $\left(R_{1}\right)$ and secondary load $\left(R_{2}\right)$. The currents of the first load, $i_{R 1}$, and secondary load, $i_{R 2}$, can be expressed as

$$
\begin{gathered}
i_{R 1}(t)=\frac{V_{o 1}}{L_{m}}\left(\frac{N_{p}}{N_{s}}\right)\left(t-t_{7}\right), \\
i_{R 2}(t)=\frac{V_{o 2}}{R_{2}}\left(t-t_{7}\right) .
\end{gathered}
$$

The equivalent circuit is shown in Fig. 12(h).

Mode 9 [Fig. 12(i), $t_{8}<t<t_{9}$ ]:

At the time $t_{8}$, the main switch $\left(S_{M}\right)$ is turned on under the ZVS conduction. During this interval, filter capacitors $\left(C_{1}\right)$ and $\left(C_{2}\right)$ continuously deliver power to the first load $\left(R_{1}\right)$ 
and secondary load $\left(R_{2}\right)$. The currents of the first load, $i_{R 1}$, and secondary load, $i_{R 2}$, can be expressed as

$$
\begin{gathered}
i_{R 1}(t)=\frac{V_{o 1}}{L_{m}}\left(\frac{N_{p}}{N_{s}}\right)\left(t-t_{8}\right), \\
i_{R 2}(t)=\frac{V_{o 2}}{R_{2}}\left(t-t_{8}\right) .
\end{gathered}
$$

The operational mode of the proposed boost converter with a transformer-capacitor cell for implementing the features of ZVS/ZCS and double-output sources over one switching cycle is completed. The equivalent circuit is shown in Fig. 12(i).

\section{Considerations of Design}

To obtain the optimum performance of the proposed boost converter, some of the important parameters must be considered. For example, the ZVS condition of the main switch and the selections of the key components will be described in this section.

\subsection{Condition of ZVS for main switch $\left(S_{M}\right)$}

Figure 13 shows the driving signal $L s$ of the switches $\left(S_{M}\right.$ and $\left.S_{a}\right)$. To achieve the ZVS feature of the main switch $\left(S_{M}\right)$, the magnetizing inductance $\left(L_{m}\right)$ of the transformer $\left(T_{r}\right)$ at the turn-on interval $\left(t_{5}-t_{6}\right)$ needs to store sufficient energy to discharge the voltage of the parasitic capacitance $\left(C_{M}\right)$. Thus, the turn-on interval $\left(t_{5}-t_{6}\right)$ of the auxiliary switch $\left(S_{a}\right)$ must be greater than the resonant interval $\left(t_{6}-t_{7}\right)$ of the magnetizing inductance $\left(L_{m}\right)$ and parasitic capacitance $\left(C_{M}\right)$. From Eqs. (19) and (24), we can obtain the following inequality:

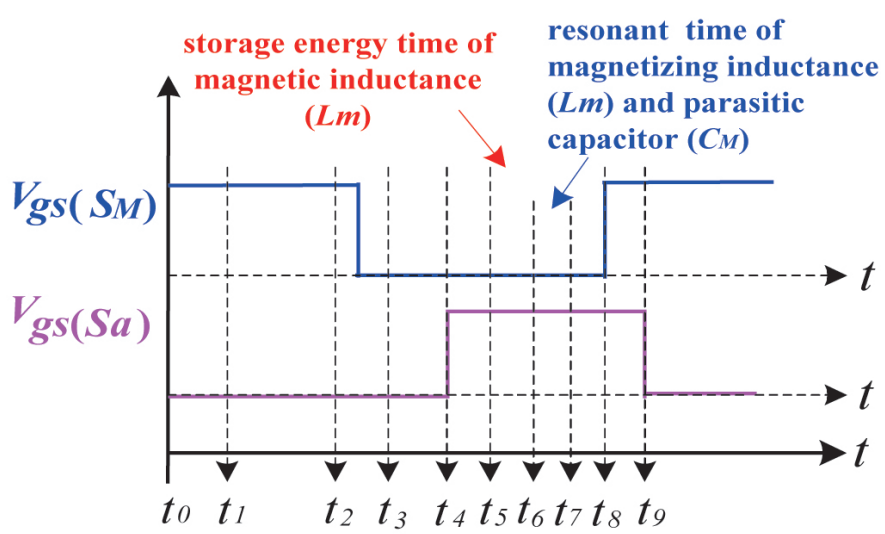

Fig. 13. (Color online) Illustration of driving signals of the switches $\left(S_{M}\right.$ and $\left.S_{a}\right)$. 


$$
T_{\text {turn-on }}=t_{6}-t_{5}=\frac{L_{m} i_{L m}}{V_{L m}}>T_{\text {resonant }}=t_{7}-t_{6}=\frac{\pi}{2} \sqrt{L_{m} C_{M}} .
$$

\subsection{Selection of magnetizing inductance $\left(L_{m}\right)$}

As shown in Fig. 10, to achieve the ZVS feature of the main switch $\left(S_{M}\right)$, the magnetizing inductance $\left(L_{m}\right)$ of the transformer $\left(T_{r}\right)$ should store sufficient energy. The current of the magnetizing inductance $\left(L_{m}\right)$ must be designed in the continuous current mode (CCM). Thus, the magnetizing inductance $\left(L_{m}\right)$ must meet the following inequality:

$$
L_{m}>L_{m b}=\frac{(1-D)^{2} R_{1}}{2 f}\left(\frac{N_{s}}{N_{p}}\right),
$$

where $L_{m b}$ is the boundary magnetizing inductance, $D$ is the duty ratio, and $f$ is the switching frequency.

\subsection{Selection of buffer capacitor $\left(C_{3}\right)$}

The main function of the buffer capacitor $\left(C_{3}\right)$ is to recover the leakage energy of the transformer when the auxiliary switch is turned off, as shown in Fig. 14. Therefore, the auxiliary switch $\left(S_{a}\right)$ can avoid spike voltage and decrease switching losses. To decrease spike voltage and switching losses, the buffer capacitor $\left(C_{3}\right)$ can be expressed as

$$
C_{3}=\frac{i_{L m(p e a k)}}{V_{o 2}} t_{f},
$$

where $t_{f}$ is the turn-off time of the auxiliary switch $\left(S_{a}\right)$.

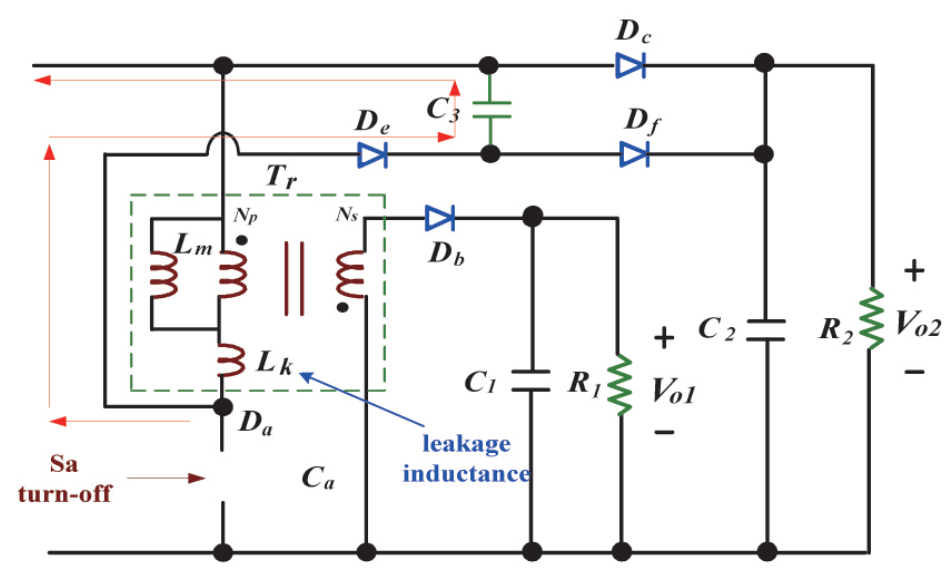

Fig. 14. (Color online) Illustration of recovery of the leakage energy of the transformer. 


\section{Simulated and Experimental Results}

To verify the feasibility of the proposed boost converter with a transformer-capacitor cell for implementing the features of ZVS/ZCS and double-output sources, a $220 \mathrm{~W}$ prototype is built. The values of its key component are shown in Fig. 15 and the specifications are listed as follows:

input voltage: $V_{S}=50 \mathrm{~V}_{\mathrm{dc}}$,

first-set output voltage: $V_{01}=15 \mathrm{~V}_{\mathrm{dc}}$,

first-set output current: $I_{01}=1 \mathrm{~A}$,

second-set output voltage: $V_{02}=200 \mathrm{~V}_{\mathrm{dc}}$,

second-set output current: $I_{02}=1 \mathrm{~A}$,

total output power: $220 \mathrm{~W}$, and

switching frequency: $f=40 \mathrm{kHz}$.

Figure 16 shows the simulated and experimental signal waveforms of the main switch $\left(S_{M}\right)$ and auxiliary switch $\left(S_{a}\right)$ at an operating frequency of $40 \mathrm{kHz}$. Figure 17 shows the simulated and experimental voltage and current waveforms of the main switch $\left(S_{M}\right)$, from which it can

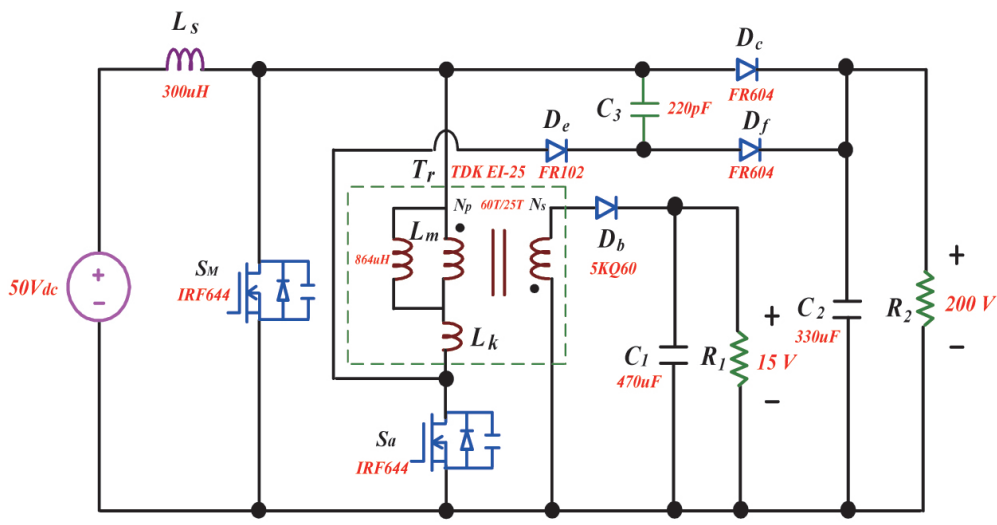

Fig. 15. (Color online) Simulated and experimental circuits of the proposed boost converter with a transformercapacitor cell for implementing the features of ZVS/ZCS and double-output sources.

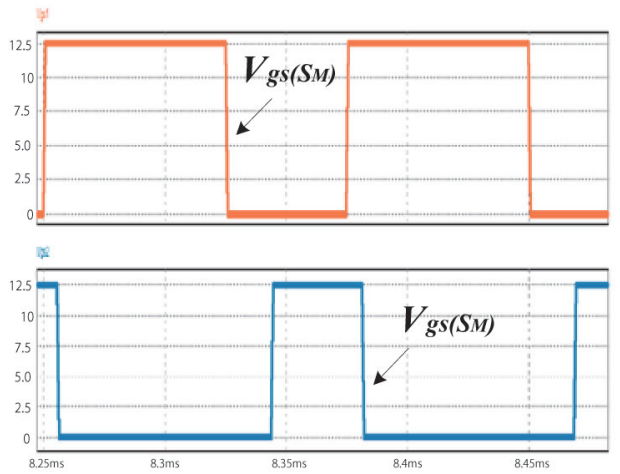

(a)

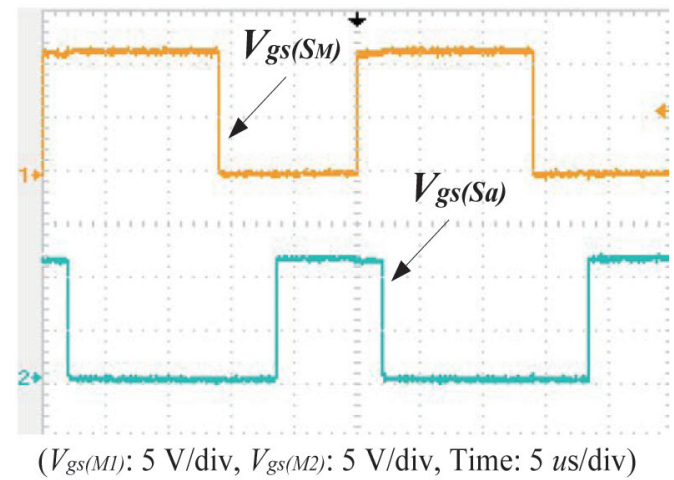

(b)

Fig. 16. (Color online) Driving signals of the main switch $\left(S_{M}\right)$ and auxiliary switch $\left(S_{a}\right)$ : (a) simulated and (b) experimental waveforms. 


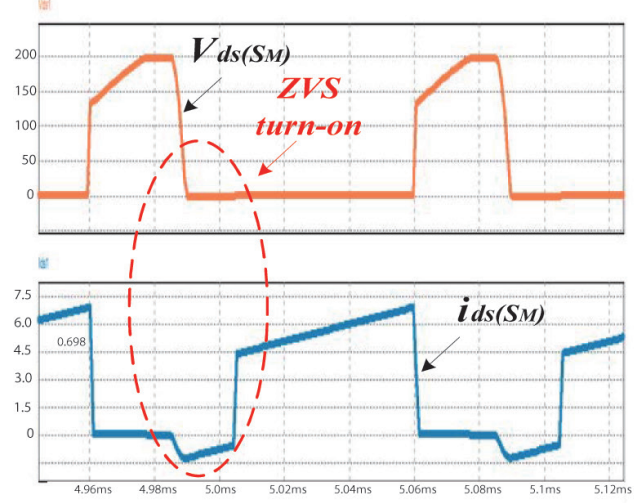

(a)

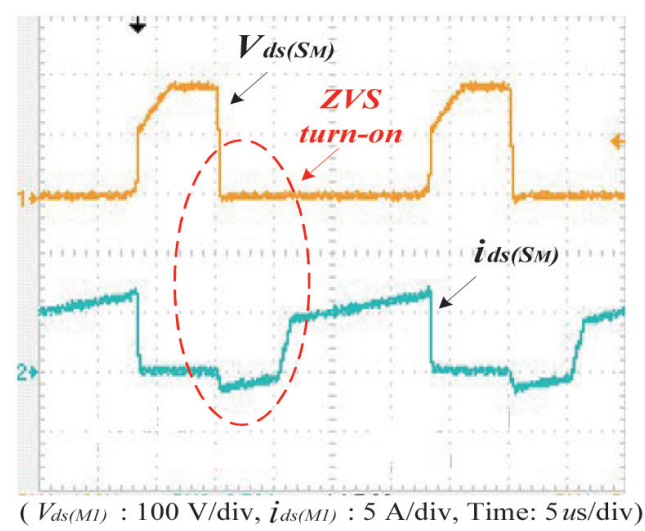

(b)

Fig. 17. (Color online) Voltage and current waveforms of the main switch $\left(S_{M}\right)$ : (a) simulated and (b) experimental waveforms.

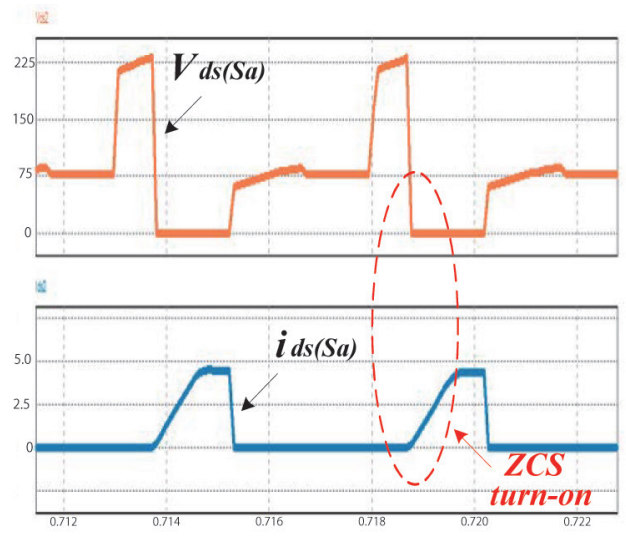

(a)

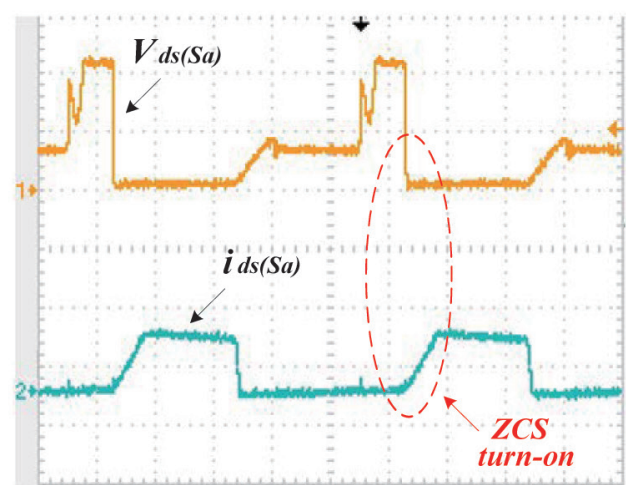

$\left(V_{d s(M 2)}: 100 \mathrm{~V} / \mathrm{div}, i_{d s(M l)}: 5 \mathrm{~A} / \mathrm{div}\right.$, Time: 5 us/div)

(b)

Fig. 18. (Color online) Voltage and current waveforms of the auxiliary switch $\left(S_{a}\right)$ : (a) simulated and (b) experimental waveforms.

be seen that the main switch $\left(S_{M}\right)$ has a ZVS feature at turn-on transition. Figure 18 shows the simulated and experimental voltage and current waveforms of the auxiliary switch $\left(S_{a}\right)$, from which it can be seen that the auxiliary switch $\left(S_{a}\right)$ has a ZCS feature at turn-on transition. Figure 19 shows the simulated and experimental voltage and current waveforms of the capacitor $\left(C_{3}\right)$, from which it can be seen that the energy of the leakage inductance $\left(L_{k}\right)$ is absorbed by the capacitor $\left(C_{3}\right)$. Figures 20 and 21 show the simulated and experimental voltage and current waveforms of power diodes $\left(D_{c}\right.$ and $\left.D_{f}\right)$, from which it can be seen that the energy stored in the capacitor $\left(C_{3}\right)$ limits the rate of reverse recovery current for power diodes $\left(D_{c}\right.$ and $\left.D_{f}\right)$ to reduce reverse recovery losses. The experimental efficiency of the boost converter compared with those of a transformer-capacitor cell and a transformer cell is obtained in Fig. 22. From Fig. 22 , it can be seen that the boost converter with a transformer-capacitor cell can obtain a higher efficiency. 


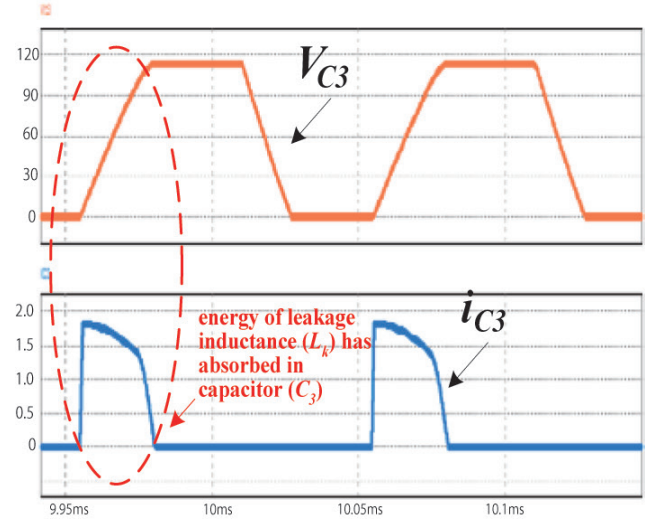

(a)

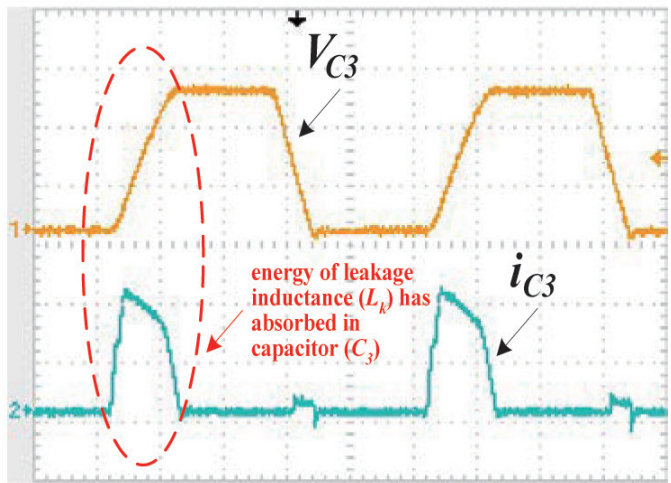

( $V_{C 3}: 40 \mathrm{~V} / \mathrm{div}, i_{C 3}: 1 \mathrm{~A} / \mathrm{div}$, Time: 5 us/div)

(b)

Fig. 19. (Color online) Voltage and current waveforms of the capacitor $\left(C_{3}\right)$ : (a) simulated and (b) experimental waveforms.

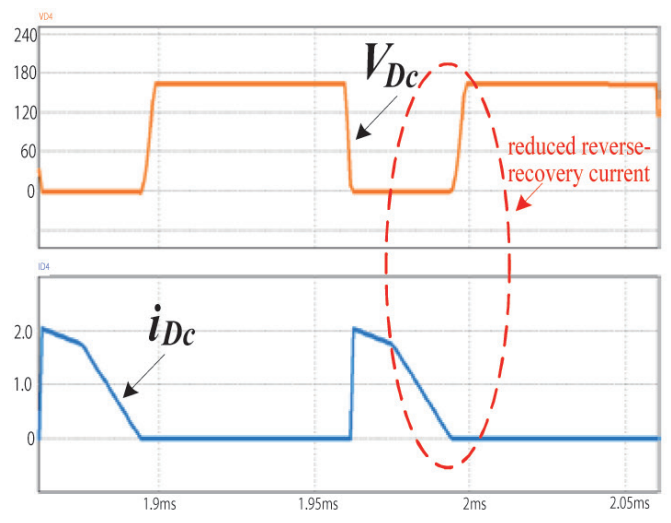

(a)

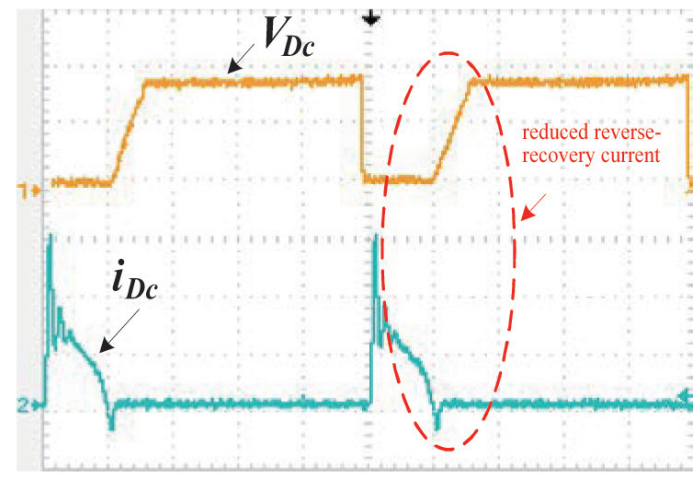

(VD4.100 V/div, $i_{D 4}: 1 \mathrm{~A} / \mathrm{div}$, Time: 5 us/div)

(b)

Fig. 20. (Color online) Voltage and current waveforms of the power diode $\left(D_{c}\right)$ : (a) simulated and (b) experimental waveforms.

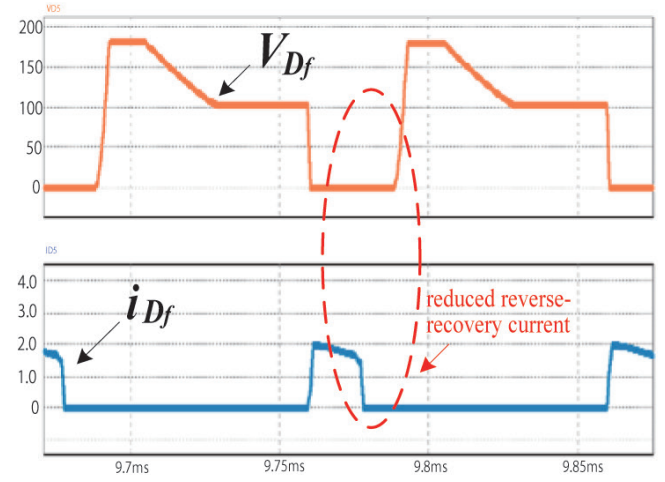

(a)

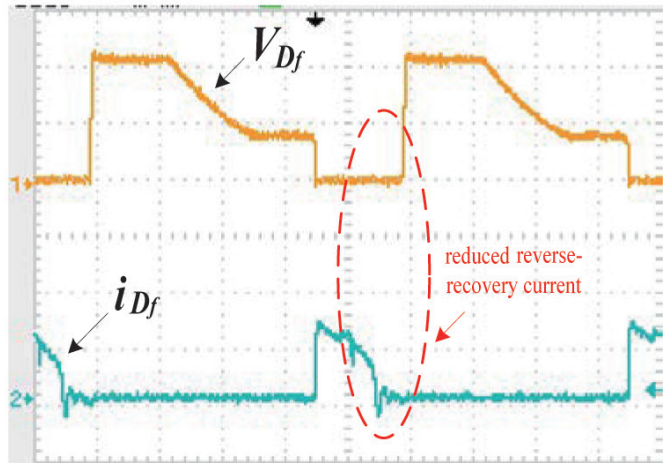

( $V_{D 5}: 100 \mathrm{~V} / \mathrm{div}, i_{D 5}: 1 \mathrm{~A} / \mathrm{div}$, Time: 5 us/div)

(b)

Fig. 21. (Color online) Voltage and current waveforms of the power diode $\left(D_{f}\right)$ : (a) simulated and (b) experimental waveforms. 


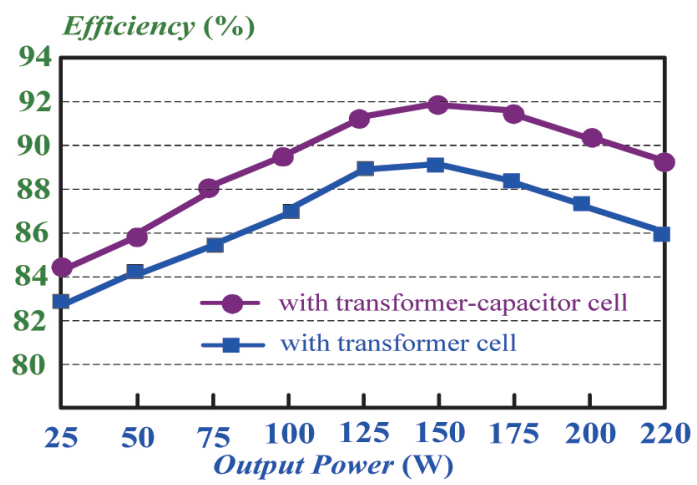

Fig. 22. (Color online) Efficiency of the proposed boost converter with a transformer-capacitor cell for implementing the features of ZVS/ZCS and double-output sources under full load condition.

\section{Conclusions}

In this study, the proposed boost converter with a transformer-capacitor cell for implementing the features of ZVS/ZCS and double-output sources has been built and implemented under turn-on transitions for the main switch $\left(S_{M}\right)$ and auxiliary switch $\left(S_{a}\right)$. Additionally, the energy trapped in the leakage inductance of the transformer can be recovered, the switching losses of power switches and diodes can be reduced, and the efficiency can be increased. The proposed boost converter can obtain double-output sources with step-up/stepdown voltage functions by applying the voltage ratios of the transformer $\left(T_{r}\right)$. Therefore, the utility of the proposed boost converter can be increased. The simulated and experimental results have verified that the proposed boost converter with a transformer-capacitor cell is relatively suitable for double-output sources with step-up/step-down voltage applications.

\section{Acknowledgments}

This work was supported by the Ministry of Science and Technology, Taiwan, under Grant No. MOST 106-2221-E-167-025.

\section{Author Contributions}

All of the authors contributed to publishing this paper. Cheng-Tao Tsai wrote the paper, and Jye-Chau Su and Sin-Ru Wei contributed to the simulated and experimental results of the circuit.

\section{Conflicts of Interests}

The authors declare that there are no conflicts of interest regarding the publication of this paper. 


\section{References}

1 C. L. Shen, P. C. Chiu, and Y. C Lee: Energies 9 (2016) 871.

2 R. Pinto, S. Mariano, M. R. Calado, and J. F. de Souza: Energies 9 (2016) 739.

3 M. A. Elsaharty, H. A. Ashour, E. Rakhshani, E. Pouresmaeil, and J. P. S. Catalão: Energies 9 (2016) 248.

4 C. T. Tsai and W. M. Chen: Energies 9 (2016) 1.

5 S. M. Chen, T. J. Liang, L. S. Yang, and J. F. Chen: IEEE Trans. Power Electron. 26 (2011) 1146.

6 C. M. Wang: IEEE Trans. Ind. Electron. 33 (2006) 768.

7 X. Wu, J. Zhang, and X. Ye: IEEE Trans. Ind. Electron. 55 (2008) 773.

8 C. M. C. Duarte and I. Barbi: IEEE Trans. Circuits Syst. I Regul. Pap. 44 (1997) 698.

9 H. Wang, H. S. Chung, and A. Ioinovici: IEEE Trans. Power Electron. 27 (2012) 2242.

10 I. V. Jeevan Adhikari and S. K. Panda: Renewable Energy 92 (2016) 562.

11 Y. S. Lee and G. T. Chen: IEEE Power Electronics Specialists Conf. 4 (2004) 2766.

12 D. H. Xu, M. Chen, J. Lou, and M. Luo: IEEE Trans. Power Electron. 19 (2004) 1408.

13 K. Jin and X. Ruan: IEEE Trans. Ind. Electron. 54 (2007) 1705.

14 L. Corradini: IEEE Trans. Power Electron. 29 (2014) 1585.

15 M. Pavlovsky, G. Guidi, and A. Kawamura: IEEE Trans. Power Electron. 29 (2014) 851.

16 H. M. Sizkoohi, J. Milimonfared, M. Taheri, and S. Salehi: IET Trans. Power Electron. 8 (2015) 1786.

17 W. Li and X. He: IEEE Trans. Power Electron. 4 (2011) 523.

18 M. R. Mohammadi and H. Farzanehfard: IEEE Trans. Ind. Electron. 62 (2015) 1471.

19 Y. Kuo, T. Liang, and J. Chen: IEEE Trans. Ind. Electron. 48 (2001) 594.

20 M. Ilic and D. Maksimovic: IEEE Trans. Ind. Appl. 43 (2007)1619.

\section{About the Authors}

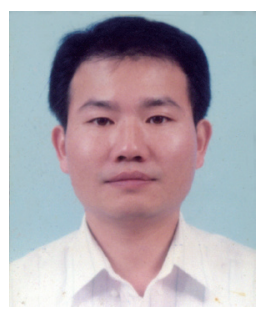

Cheng-Tao Tsai received his B.S. degree in electrical engineering in 1991 from Feng Chia University, Taichung, Taiwan, and his M.S. and Ph.D. degrees from National Chung Cheng University, Chia-Yi, Taiwan, in 2003 and 2008, respectively. Recently, he has joined National Chin-Yi University of Technology, Taichung, Taiwan, where he is currently a professor in the Department of Electrical Engineering. His current research interests include the design of switching-mode power supplies, power factor correction technology, and chargers for electric vehicles.

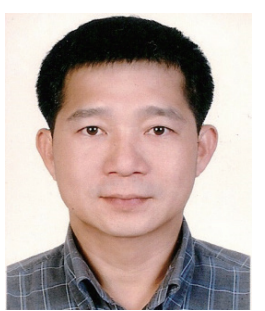

Jye-Chau Su received his B.S. degree in electrical engineering from TamChun University, Taiwan, in 1991 and his M.S. degree in electrical engineering from Fairleigh Dickinson University, USA, in 1998. He is currently working toward a Ph.D. degree at the Graduate Institute of Engineering Science and Technology, National Kaohsiung University, Taiwan. His research interests include converters, inverters, and vehicle power management.

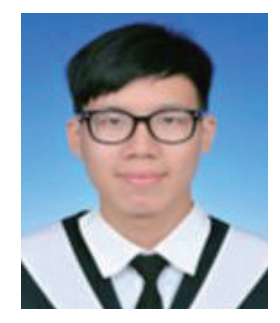

Sin-Ru Wei received his B.S. degree in electrical engineering in 2017 from National Chin-Yi University of Technology, Taiwan. His research is on switching-mode power supplies. 